\title{
Changing electrophoretic patterns of glutamate dehydro- genases and aspartate aminotransferases in a few tree species under the influence of ectomycorrhization
}

\author{
B. Botton ${ }^{1}$, M. Chalot ${ }^{1}$ and B. Dell ${ }^{2}$ \\ 1 Université de Nancy l, Faculté des Sciences, Laboratoire de Physiologie Végétale et Forestière, \\ BP 239, 54506 Vandoeuvre-lès-Nancy Cedex, France, and \\ 2 Murdoch University, School of Biological and Environmental Sciences, Murdoch, Western Austra- \\ lia, 6150 Australia
}

\section{Introduction}

Numerous studies have demonstrated the widespread existence of two systems for nitrogen assimilation in plants and microorganisms: the glutamate dehydrogenase (GDH) pathway and the glutamine synthetase (GS)/glutamate synthase (GOGAT) cycle. While the GS/GOGAT pathway is operative in higher plants (Lea and Miflin, 1974), ammonia assimilation in fungi generally occurs via the GDH pathway (Pateman and Kinghorn, 1975), although some non-mycorrhizal fungi seem capable of utilizing the alternative glutamine synthetase/glutamate synthase route (Kusnan et al., 1987). In mycorrhizal associations, preliminary data have shown that the fungal pathways of nitrogen assimilation in beech-mycorrhizas are modified by the establishment of the symbiosis and that glutamate dehydrogenase plays a minor role in this process (Martin et al., 1986). Taking these observations into account, we studied a few ectomycorrhizal associations, focusing on GDH and aspar- tate aminotransferase (AAT), an enzyme which converts glutamate into aspartate.

\section{Materials and Methods}

Norway spruce (Picea excelsa) roots and Hebeloma sp. ectomycorrhizas were obtained from 4 yr old plants grown under nursery conditions. Douglas fir (Pseudotsuga douglasii) roots either non-mycorrhizal or ectomycorrhizal with Laccaria laccata (strain S 238) were collected from $1 \mathrm{yr}$ old seedlings grown under nursery conditions. Beech (Fagus sylvatica) roots and Paxillus involutus (Naudet strain) ectomycorrhizas as well as Hebeloma crustuliniforme ectomycorrhizas were collected from 4-6 mo old seedlings grown in a pasteurized peat mix under nursery conditions. The fungi were cultivated in pure culture in Pachlewski's medium.

Enzyme activities and protein concentration were determined according to methods described elsewhere (Khalid et al., 1988; Dell et al., 1989). Electrophoresis was carried out on $6 \%$ polyacrylamide slab gels. The bands of NADP-GDH and NAD-GDH activities were located by using a tetrazolium assay system (Blumenthal and Smith, 1973) and AAT activity was revealed with Fast violet blue (Khalid et al., 1988). 
Table I. Specific activities (nkat/mg protein) of GDH and AAT in spruce and beech ectomycorrhizas and in the free-living partners of the associations.

\begin{tabular}{lcll}
\hline & NADP-GDH & NAD-GDH & AAT \\
\hline Spruce-Hebeloma mycorrhizas & 6.2 & 1.5 & 13.1 \\
Non-mycorrhizal spruce roots & $\beth^{0}$ & 0.8 & 22.0 \\
Free-living fungus (Hebeloma sp.) & 20.0 & 0.8 & 18.4 \\
Beech-Hebeloma mycorrhizas & 0.2 & 2.7 & 15.5 \\
\hline
\end{tabular}

\section{Results}

In the free-living fungus Hebeloma sp. a high level of NADP-GDH activity was found, whereas only NAD-GDH activity was detected in non-mycorrhizal roots. In the association spruce-Hebeloma, both activities were present (Table I). A similar distribution of enzyme activities was observed in the Douglas fir- $L$. laccata association (not shown).

These results contrast with those obtained with Beech ectomycorrhizas where NADP-specific activity was very low (Table I). Identical data were also obtained with the associations beech- $P$. involutus and Beech-H. crustuliniforme (not shown).

In the Spruce-Hebeloma sp. association, gel electrophoresis confirmed the presence of NAD-GDH in the host cells (one band) and the presence of a high level of NADP-GDH activity in the fungus (one major band and one minor band). Both GDHs were detected in spruce ectomycorrhizas (Fig. 1A). In the Beech- $H$. crustuliniforme association, the single band of NADP-GDH activity found in the fungus was represented as traces in the mycorrhiza, which exhibited a high level of NAD-GDH activity as did the non-mycorrhizal roots (Fig. 1B).

As for aspartate aminotransferase, the distinct isoforms found in mycorrhizas, always corresponded to the host root isoforms, whereas the fungal form found in the fungus cultivated in pure culture was not detected. Dissection of the mycorrhizal tissues in spruce confirmed these results: the vascular cylinder free of fungus and the cortical region including host cells and fungal hyphae revealed identical isoforms, while no activity was found in the peripheral mycelial layer (Table II).
A SPRUCE-IIEBELOMA SP.

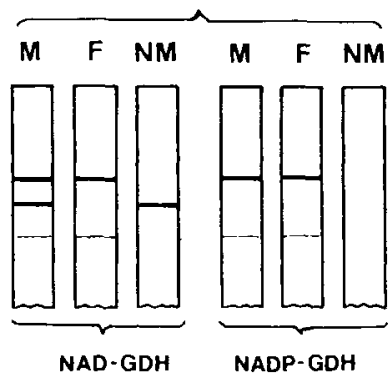

B BEECH-HEBELOMA CRUSTULINIFORME

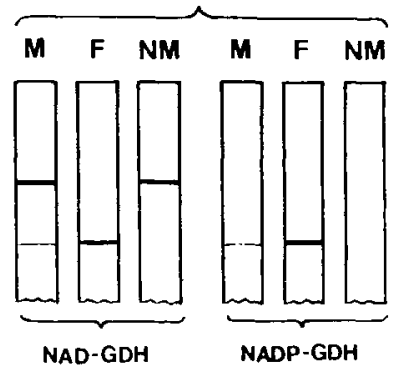

Fig. 1. Electrophoretic patterns of NAD-GDH and NADP-GDH extracted from the ectomycorrhizas (M), the freeliving fungus (F) and non-mycorrhizal roots (NM). $25 \mu \mathrm{g}$ of protein (crude extract) were added to each well. 
Table II. AAT activity and pattern of the enzyme in gels from different tissues of the spruce-Hebeloma sp. association.

\begin{tabular}{lcllll}
\hline Tissues & $\begin{array}{c}\text { Specific activity } \\
\text { (nkat/mg protein) }\end{array}$ & \multicolumn{3}{l}{ AAT activity detected } \\
\cline { 5 - 7 } & bands & $\mathrm{R}_{\text {, }}$ & \\
\hline Non-mycorrhizal roots & 13 & 2 & 0.52 & 0.58 \\
Whole mycorrhiza & 6.3 & 2 & 0.52 & 0.58 \\
Peripheral mycelium & traces & none & & \\
Sheath + Hartig net & 5 & 2 & 0.52 & 0.58 \\
Vascular cylinder & 8.7 & 2 & 0.52 & 0.58 \\
Fungus in pure culture & 11.5 & 1 & 0.28 & \\
\hline
\end{tabular}

\section{Conclusion}

In all the associations investigated, fungal AAT was strongly repressed, whereas fungal NADP-GDH was only repressed in beech-ectomycorrhizas. These results suggest that the repression may come from the host plant, since the same fungus gives rise to two kinds of responses depending upon the plants. However, to date, the mechanism of repression remains unknown.

\section{References}

Blumenthal K.H. \& Smith E.L. (1973) Nicotinamide adenine dinucleotide phosphate-specific glutamate dehydrogenase of Neurospora. J. Biol. Chem. 248, 6002-6008
Dell B., Botton B., Martin F. \& Le Tacon F. (1989) Glutamate dehydrogenases in ectomycorrhizas of spruce (Picea excelsa L.) and beech (Fagus sylvatica L.). New Phytol. 111, 683-692

Khalid A., Boukroute A., Botton B. \& Martin F. (1988) The aspartate aminotransferase of the ectomycorrhizal fungus Cenococcum geophilum: purification and molecular properties. Plant Physiol. Biochem. 26, 17-28

Kusnan M.B., Berger M.G. \& Fock H.P. (1987) The involvement of glutamine synthetase/glutamate synthase in ammonia assimilation by Aspergillus nidulans. J. Gen. Microbiol. 123, 1235-1242

Lea P.J. \& Miffin B.B. (1974) An alternative route for nitrogen assimilation in higher plants. Nature 251, 614-616

Martin F., Stewart G.R., Genetet I. \& Le Tacon F. (1986) Assimilation of $15 \mathrm{NH}_{+}^{+}$by beech (Fagus sylvatica L.) ectomycorrhizas. New Phytol. 102, 85-94

Pateman J.A. \& Kinghorn J.R. (1975) Nitrogen metabolism. In: The Filamentous Fungi. Vol. 2, (Smith J.E. \& Berry D.R., eds.). Edward Arnold, London, pp. 159-237 